\title{
Effects of substrate selection and post-settlement survival on recruitment success of the thalassinidean shrimp Neotrypaea californiensis to intertidal shell and mud habitats
}

\author{
Kristine L. Feldman ${ }^{1, *}$, David A. Armstrong ${ }^{1}$, David B. Eggleston ${ }^{1, * *}$, Brett R. Dumbauld ${ }^{2}$ \\ ${ }^{1}$ School of Fisheries, Box 357980, University of Washington, Seattle, Washington 98195, USA \\ ${ }^{2}$ Washington State Department of Fish and Wildlife, Willapa Bay Field Station, PO Box 190, Ocean Park, Washington 98640, USA
}

\begin{abstract}
We quantified recruitment of young-of-the-year (YOY) burrowing thalassinidean shrimp Neotrypaea californiensis to 2 habitats of differing structural complexity-epibenthic bivalve shell and bare mudflat-and examined how differential settlement and post-settlement predation influence patterns of YOY abundance. Local densities of shrimp were quantified prior to construction of shell habitat in Grays Harbor estuary, Washington (USA). Subsequent recruitment of YOY shrimp to epibenthic shell and bare mudflat was measured during a peak settlement pulse and 10 mo post-settlement. In addition, patches of sediment overlying shell within the shell plot ('subsurface shell') were sampled 10 mo post-settlement. Differential settlement in shell and mud habitats was quantified in field and laboratory experiments. We also examined predator-prey interactions between YOY Dungeness crabs Cancer magister and newly settled shrimp in shell habitat in a laboratory experiment in which prey consumption $\mathrm{crab}^{-1}$ was quantified as a function of shrimp density. Results of our studies indicate that dense coverage of epibenthic shell applied to the intertidal site reduced recruitment of ghost shrimp. Epibenthic shell habitat had significantly fewer YOY shrimp than bare mudflat at peak settlement and 10 mo post-settlement, and significantly fewer shrimp than 'subsurface shell' at 10 mo post-settlement. Successful colonization of 'subsurface shell' suggests that shrimp postlarvae settled preferentially in areas of the shell plot covered with mud or possibly were exposed to lower levels of predation than in contiguous epibenthic shell areas. Results of the field experiment revealed that 2 to 5 times fewer shrimp postlarvae settled in shell than mud treatments; a similar but non-significant trend of lower settlement in shell than mud substrate was observed in the laboratory habitat-choice experiment. YOY Dungeness crabs preyed on shrimp in the laboratory experiment; prey density had a significant effect on consumption rates but not on proportional shrimp mortalities. In sum, although other processes most likely contributed to patterns of YOY shrimp distribution, postlarval habitat selection for mud substrate was a key determinant of recruitment success. Recruitment patterns may be further modified by postsettlement mortality of YOY shrimp in shell due to YOY Dungeness crab predation.
\end{abstract}

KEY WORDS: Neotrypaea californiensis - Cancer magister - Thalassinid shrimp - Dungeness crab . Recruitment - Settlement Predation - Intertidal

\section{INTRODUCTION}

Variation in recruitment success of benthic marine invertebrates reflects in part the combination of differ-

\footnotetext{
·E-mail: kfeldman@fish.washington.edu

- Present address: Department of Marine, Earth, and Atmospheric Sciences, North Carolina State University, Raleigh, North Carolina 27695-8208, USA
}

ential settlement and post-settlement mortality associated with specific habitats. Structural complexity and heterogeneity influences settlement of sessile and mobile invertebrates to hard surfaces (Bourget et al. 1994, Jacobi \& Langevin 1996, Lemire \& Bourget 1996) as well as settlement of mobile organisms to softbottom sediments. In the latter case, postlarval settlement of epibenthic or shallow burrowing mobile decapod crustaceans is enhanced in habitats including rock 
crevices (Botero \& Atema 1982), complex algae and seagrasses (Hermkind \& Butler 1986, Johns \& Mann 1987. Fernandez et al. 1993b), and epibenthic bivalve shell (Fernandez et al. 1993b, Eggleston \& Armstrong 1995), Under natural tidal flows, patterns of enhanced settlement in non-uniform, structurally diverse habitats are influenced by both hydrodynamic processes (Eckman 1983, Snelgrove et al. 1993) and active substrate selection (Fernandez et al. 1993b, Eggleston \& Armstrong 1995). The relative importance of each process varies with the spatial scale of interest as well as the organism's swimming capability (Butman 1987). In addition to enhancing settlement, complex habitats provide juveniles greater refuge from predators than relatively uniform habitats (Johns \& Mann 1987, Barshaw \& Lavalli 1988, Eggleston et al. 1990, Wilson et al. 1990, Fernandez et al. 1993b).

Although complex habitats have a positive effect on the settlement and survival of many mobile species, they may effectively exclude colonization by other benthic invertebrates such as deep-burrowing macrofauna. Discrete assemblages in which burrowers are largely excluded could result from reduced mobility in a bed comprised of high densities of sedentary organisms or other material inhibiting burrowing (i.e mobility-mode hypothesis, see Posey 1990 and references therein). For example, structurally complex rootrhizome mats associated with seagrass beds have been shown to reduce the mobility of several burrowing species (Brenchley 1982) and to limit the distribution of burrowers to areas outside these habitats (Ringold 1979, Harrison 1987, Swinbanks \& Luternauer 1987). Similar findings of reduced mobility have been reported in dense beds of tube-building polychaetes (Brenchley 1982) and phoronids (Ronan 1975). In both habitat types, the extent to which roots and tubes are capable of excluding burrowing organisms is a function of root or tube density, size and body morphology of the burrower, and degree of mobility (Brenchley 1982). The studies noted above correlate the reduction of burrowers in complex substrates to the presence of material that hinders their mobility; however, distribution patterns could be the result of differential settlement, mortality, or movement associated with habitats of varying complexity.

The ghost shrimp Neotrypaea californiensis (formerly Callianassa californiensis; Manning \& Felder. 1991 ) is a highly mobile burrowing decapod crustacean (Thalassinidea, Callianassidae) common in estuarine intertidal sediments along the Pacific coast of North America from southeast Alaska to Baja California (Stevens 1928, MacGinitie 1934). Extensive semipermanent burrow systems are constructed during the course of deposit feeding (MacGinitie 1934, Brenchley 1981, Bird 1982), typically ranging up to $50 \mathrm{~cm}$ depth with multiple openings to the surface (Swinbanks \& Murray 1981, Swinbanks \& Luternauer 1987). At high densities, ghost shrimp can greatly influence community composition by excluding species that are unable to withstand the constant disruption of sediment caused by the continuous turnover of near-surface sediments (Peterson 1977, Brenchley 1981, Bird 1982, Murphy 1985, Posey 1986a, Dumbauld 1994). Other species of thalassinid shrimps are reported to have similar effects on benthic infaunal species assemblages (Aller \& Dodge 1974, Tamaki 1988, Posey et al. 1991) and seagrass beds (Suchanek 1983).

In Grays Harbor, Washington (USA), the success of an intertidal shell mitigation program to enhance recruitment success of Dungeness crabs Cancer magister may be threatened in part by Neotrypaea californiensis and another thalassinid shrimp, Upogebia pugettensis. In estuarine environments, young-of-theyear (YOY: settlement to age 1) crab density is significantly higher in sheltered habitats, such as epibenthic bivalve shell, than on bare mudflat (Armstrong \& Gunderson 1985, Dumbauld et al. 1993) due to a combination of active substrate selection and reduced predation risk (Fernandez et al. 1993b, Eggleston \& Armstrong 1995). From 1990 to 1991, small-scale test plots were established throughout Grays Harbor to assess the feasibility of using oyster shell to mitigate loss of an estimated 162000 subadult 2 yr old crabs that occurred during the widening and deepening of the main navigation channel by the U.S. Army Corps of Engineers (COE) (Armstrong et al. 1991, 1992, Wainwright et al. 1992). Surveys of test plots revealed a significant negative relationship between areal density of shrimp burrow openings and percent shell cover (Armstrong et al. 1992). At sites where burrow openings exceeded $150 \mathrm{~m}^{-2}$, the integrity of shell habitat (i.e. epibenthic structure usable as crab refuge) was reduced to $0-10 \%$ just 1 to 2 mo after construction; however, shell integrity was greater than $50 \%$ at sites with fewer than 50 burrow openings $\mathrm{m}^{-2}$. The loss of shell was largely due to subsidence and on-site sedimentation caused by the burrowing activities of the shrimp (Armstrong et al. 1992).

Full-scale shell mitigation was initiated in 1992 at a site with relatively low densities of Neotrypaea californiensis; however, it was not known whether YOY ghost shrimp would settle and survive in these structurally complex shell habitats, thereby contributing to their eventual degradation, or whether the shell barrier and resident YOY Dungeness crabs would reduce recruitment of YOY shrimp. Our study consisted of 3 objectives: (1) to quantify the density of ghost shrimp prior to shell plat construction and subsequent recruitment of newly settled YOY shrimp in shell and mud habitats; (2) to examine differential settlement of 
shrimp postlarvae in shell and mud substrates that might account for patterns of post-settlement densities; and (3) to assess whether YOY Dungeness crabs prey on newly settled shrimp in shell habitat and how foraging behavior is affected by variable shrimp densities.

\section{MATERIALS AND METHODS}

Study area. Grays Harbor, located on the Pacific coast of Washington, USA $\left(46^{\circ} 55^{\prime} \mathrm{N}, 124^{\circ} 10^{\prime} \mathrm{W}\right)$, is a large $\left(235 \mathrm{~km}^{2}\right.$ at mean higher high water) shallow estuary with semidiurnal tides that range up to $4 \mathrm{~m}$ (Fig. 1). Approximately $60 \%$ of the surface area is intertidal, portions of which are covered by eelgrass Zostera marina and light to moderate densities of epibenthic bivalve shell (relic deposits of eastern softshell clam Mya arenaria and live culture of Pacific oyster Crassostrea gigas). Ghost shrimp are common inhabitants of intertidal sediments throughout the estuary, but dense beds (e.g. $>100$ burrow openings $\mathrm{m}^{-2}$ ) tend to be concentrated in the northern portion of the bay. Another thalassinid, Upogebia pugettensis, is present in the estuary as well but at lower densities (Armstrong et al. 1992).

Shell habitat construction was initiated in April 1992 at 2 intertidal locations chosen by the COE. The 'Pacman' site was located in the northeastern section of the bay, and the 'South Channel' site was located in

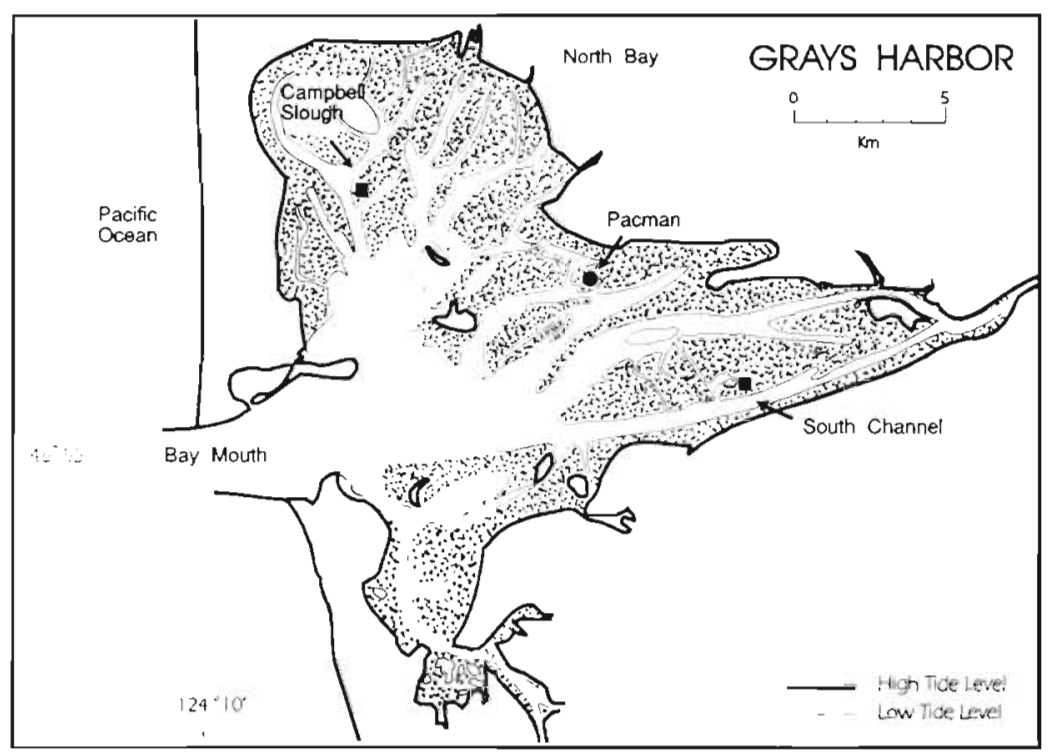

Fig. 1 Grays Harbor estuary (Washington, USA) showing the location of Pacman and South Channel, the 2 full-scale U.S. Corps of Engineers' shell plots. Pacman was the site chosen for this study since shrimp densities were extremely low at the South Channel site. Also shown is Campbell Slough, the site of the August 1993 settlement experiment. Stippling indicates intertidal mudflat exposed at mean lower low water the southeastern section of the bay (Fig. 1). Due to extremely low density of ghost shrimp in the area chosen for shell deposition at South Channel, only results from Pacman are reported. All field work was conducted at Pacman except for a settlement experiment in 1993, which was conducted at Campbell Slough (Fig. 1), the site of one of the 1991 test plots in North Bay. The Pacman site was characterized in 1991 by relatively low densities of ghost shrimp $<50$ burrows openings $\mathrm{m}^{2}$ ) and eelgrass turions ( $<20$ turions $\mathrm{m}^{-2}$; Armstrong et al. 1992).

Prior to shell deposition in 1992, the COE surveyed the local area at Pacman and intentionally selected an area of mudflat with relatively low densities of burrow openings $\left(\bar{x}=66\right.$ openings $\left.\mathrm{m}^{-2}, \mathrm{SD}=30\right)$ to minimize shell loss. Our efforts to find an adjacent control area with comparable burrow densities were unsuccessful; thus, we had to establish a mud control plot in an area with higher burrow densities $\left(\bar{x}=89\right.$ openings $\mathrm{m}^{-2}$, $\mathrm{SD}=38$ ). The shell plot measured $60 \mathrm{~m} \times 360 \mathrm{~m}$ (2.2 ha), and at the time of construction the shell layer stood 10 to $15 \mathrm{~cm}$ above the sediment surface. The control plot, consisting of bare mudflat, was established $50 \mathrm{~m}$ from the shell plot at the same tidal elevation and proximity to the subtidal channel. The shell plot and control plot were equal in dimension and were staked off into $20 \mathrm{~m} \times 20 \mathrm{~m}$ subplots for random sampling.

Pre-treatment shrimp density. Shrimp abundance was quantified prior to construction of the shell plot to reveal any pre-existing patterns in shrimp density between the treatment (addition of shell) and control plots (i.e. all samples were collected from undisturbed mudflat). Shrimp were sampled during April and May 1992 with a stainless steel core $(40 \mathrm{~cm}$ diameter $\times 60 \mathrm{~cm}$ height). Contents of the core were excavated by shovel and sieved on a $3 \mathrm{~mm}$ mesh screen. This mesh size targeted adult and juvenile shrimp while enabling us to process large quantities of sediment. Although some juvenile shrimp may have passed through the $3 \mathrm{~mm}$ mesh, the retention efficiency of the screen was assumed to be consistent across locations since all sediments consisted of muddy sand. Shrimp were counted and measured [carapace length (CL): tip of the rostrum to the posterior margin of the cardiac region] to the nearest $0.1 \mathrm{~mm}$ with vernier calipers. Five random samples were taken from the mudflat designated for shell deposition and 5 from the control plot. A 2-sample t-test 
was used to test for a difference in mean shrimp density between the treatment and the control plot.

Post-treatment YOY shrimp density. YOY shrimp abundance in the shell and control plots was quantified over 2 periods: (1) June through August 1992 to estimate recruitment success of the 1992 year class (YC) soon after settlement, and (2) June 1993 to estimate densities of the $1992 \mathrm{YC}$ approximately 1 yr after construction of the shell plot. Although Neotrypaea californiensis postlarvae typically settle from August through October (Bird 1982, Dumbauld et al. 1996), sampling was initiated in June 1992, due to reports of El Niño oceanographic conditions (i.e. coastal sea surface temperatures elevated 3 to $4^{\circ} \mathrm{C}$ ). We anticipated the possible early arrival of ghost shrimp postlarvae based on observations that influx of Dungeness crab megalopae into Grays Harbor may be accelerated by 1 to 2 mo in El Niño years (D. Armstrong pers. obs.). We were unable to extend the sampling period into September and October due to the lack of adequate daylight low tides.

In 1992, samples were collected from epibenthic shell and mud substrates. A sampling method was devised so that data could be collected simultaneously for studies on YOY Dungeness crabs and shallow macrofauna (Armstrong et al. 1992), as well as deeper burrowing YOY shrimp. The shell plot was sampled by randomly selecting subplots and tossing a $0.10 \mathrm{~m}^{2}$ quadrat haphazardly in an area covered with $100 \%$ epibenthic shell. Shell and the top $5 \mathrm{~cm}$ of sediment underneath were removed and rinsed on a $1 \mathrm{~mm}$ mesh screen. Samples were sorted for YOY Dungeness crabs and all benthic epifauna and infauna including shrimp. Once excavation of the top $5 \mathrm{~cm}$ was complete, a $0.05 \mathrm{~m}^{2}$ core $(25 \mathrm{~cm}$ diameter) was placed inside the quadrat and an additional $15 \mathrm{~cm}$ of sediment was removed, rinsed on a $1 \mathrm{~mm}$ mesh screen, and sorted for shrimp only. A $1 \mathrm{~mm}$ mesh dip net was used to recover shrimp from samples in which the bottom of the core had flooded with water which happened occasionally in the shell and control plots. The same method was used to collect samples from the control plot $(n=12$ in each habitat). We tested the efficiency of the $1 \mathrm{~mm}$ mesh screen and found it to be $94 \%$ effective at retaining YOY shrimp: shrimp ranging in size from 1.5 to $3.7 \mathrm{~mm} \mathrm{CL}$ were retained by the $1 \mathrm{~mm}$ mesh while postlarvae (1.2 mm CL) were retained by a $0.5 \mathrm{~mm}$ mesh. We concluded that the $1 \mathrm{~mm}$ mesh was adequate for sampling post-settlement density; however, a $0.5 \mathrm{~mm}$ mesh screen was used in settlement and predator-prey experiments described below to ensure retention of all postlarvae and older juveniles for these studies. A $0.5 \mathrm{~mm}$ mesh size has been shown to effectively capture all planktonic larval stages (I to $V$ ) of Neotrypaea californiensis (Johnson \& Gonor 1982).
Ghost shrimp were counted and measured (CL) to the nearest $0.1 \mathrm{~mm}$ using an ocular micrometer. Shrimp were assigned a settlement year class of 1991 or 1992 (YOY) based on visual assessment of size frequency histograms (see Fig 2) as well as published data on size at settlement and growth rates (Dumbauld et al. 1996). Densities of shrimp from the 2 excavation methods were converted to a common measurement of area $\left(1 \mathrm{~m}^{2}\right)$ and summed for graphical and statistical analyses. In August 1992, we also examined the depth distribution of YOY shrimp. A $0.05 \mathrm{~m}^{2}$ core was inserted into bare sediment within the control plot to $20 \mathrm{~cm}$ depth, and sediment was excavated in $5 \mathrm{~cm}$ layers and rinsed separately on a $0.5 \mathrm{~mm}$ mesh screen to retain shrimp $(n=8)$. Shrimp were measured (CL) to the nearest $0.1 \mathrm{~mm}$ using an ocular micrometer. Numbers and lengths of shrimp were used to calculate the proportion of YOY (1992 YC) and 1 yr old shrimp (1991 YC) within each depth interval.

One year after construction, a considerable amount of shell in the mitigation plot lay buried under sediment due to a combination of subsidence and sedimentation, resulting in part from the burrowing activities of shrimp that were present when the plot was created. In fact, shell burial began within weeks of deployment ( 5 to $12 \mathrm{~cm}$ depth within 2 to $4 \mathrm{mo}$ ), and by August 1992, visual estimates of percent shell cover averaged only $30 \%$ (D. Armstrong unpubl. data). Hence, in June 1993, sediment-covered-shell (hereafter referred to as 'subsurface shell') as well as $100 \%$ epibenthic shell and the control plot were sampled for YOY shrimp (1992 YC). Since no data were taken on crab density, shrimp samples were collected in a similar manner as in 1992, except that only the $0.05 \mathrm{~m}^{2}$ core was used to excavate the top $20 \mathrm{~cm}$ of sediment ( $n=10$ in each habitat).

Based on a visual analysis of size frequency histograms, all shrimp recovered from samples collected in June and July 1992, belonged to the $1991 \mathrm{YC}$ (see Fig. 2) and were excluded from statistical analyses since they had settled and established burrows before the shell plot was constructed. By August 1992, YOY shrimp were present in samples, and analyses focused entirely on this year class. Results of the pre-treatment shrimp density analysis dictated the kinds of statistical tests we could use to analyze YOY shrimp densities. If no significant difference in pre-treatment shrimp density was found between shell and control plots, then YOY densities would be analyzed with a 2-sample t-test for August 1992 data and a 1-way ANOVA for June 1993 data. However, if a significant difference existed between plots prior to shell treatment, then an odd's ratio design would be used to test for differences in YOY densities between habitats (Skalski \& Robson 1992). The odd's ratio can be used in environmental 
assessment and impact studies when test locations are chosen non-randomly; thus, treatment and control areas may be inherently different prior to treatment application. The test statistic $D$ corrects for this initial difference by incorporating both pre- and posttreatment densities and variances so that proportional changes in the treated plot can be compared to proportional changes in the control plot

Settlement (field). An experiment was conducted during the new moon spring-tide series in August 1992 and 1993 to identify potential differential settlement patterns between shell and mud substrates under natural tidal flows. Based on low counts of postlarvae in the 1992 trial at Pacman, the experiment was moved to a dense ghost shrimp bed in North Bay (Campbell Slough; Fig. 1) in 1993, and only results from the 1993 trial at Campbell Slough are reported. This location was chosen with the expectation that settlement densities would be greater than Pacman over the $3 \mathrm{~d}$ duration of the experiment based on high densities of adult ghost shrimp (>500 burrows $\mathrm{m}^{-2}$; Armstrong et al. 1992) and the presence of many newly settled shrimp on the mudflat [Neotrypaea californiensis postlarvae, $\leq 1.3 \mathrm{~mm} \mathrm{CL}: \bar{x}=263$ shrimp $\mathrm{m}^{-2}, \mathrm{SD}=97, \mathrm{n}=10$ core samples $\left(0.05 \mathrm{~m}^{2} \times 15 \mathrm{~cm}\right.$ depth, $0.5 \mathrm{~mm}$ screen)\}. We had no a priori reason to believe that habitat preferences would differ with respect to location within the bay, and hence we assumed that results from Campbell Slough would be applicable to Pacman since we were only interested in relative differences between shell and mud treatments

Thirty perforated plastic trays $\left(0.25 \mathrm{~m}^{2} \times 9 \mathrm{~cm}\right.$ height $)$ were lined with 2 layers of $1 \mathrm{~mm}$ mesh to contain the substrate and prevent postlarvae from burrowing through $1 \mathrm{~cm}$ holes in the bottoms and sides of the trays. Fifteen trays were filled with a layer of mud followed by an equal layer (by volume) of epibenthic oyster shell, and 15 were filled completely with mud. The substrate within the trays was flush with the upper lips of the trays for shell and mud treatments. Mud was collected from the site $2 \mathrm{wk}$ prior to the experiment, sieved on a $0.5 \mathrm{~mm}$ mesh screen, and allowed to dry to ensure removal of all postlarval shrimp. Each substrate type was assigned to 1 of 3 cage treatments to measure the potential short-term impact of predators on postlarval survival. Five trays were left exposed, 5 covered with a full cage, and 5 covered with a control cage. Cages $\left(0.25 \mathrm{~m}^{2} \times 15 \mathrm{~cm}\right.$ height) were constructed with $1.3 \mathrm{~cm}$ wire mesh with PVC (polyvinylchloride) stakes attached to the corners. Two sides on control cages were shortened slightly to mimic the physical structure of the cage as much as possible while allowing entry of small crabs and fishes (e.g. Virnstein 1978, Hurlberg \& Oliver 1980). Shortened sides were oriented parallel with ebb and flood tidal currents to limit differences in flow across full and control cages
Trays were placed 2 to $3 \mathrm{~m}$ apart on the sediment in a single row approximately normal to both tidal flow across the mudflat and to a nearby subtidal channel (ca $50 \mathrm{~m}$ away). Due to the configuration of the tideflat, distance of the trays from the subtidal channel was used as a blocking factor to account for variation in settlement that might result from increasing immersion time. The 30 trays were divided into 5 blocks so that each block contained 1 of the 6 treatment combinations. Individual treatments were randomly interspersed within each block (Underwood 1981). Wire brushes were used to scrub the cages daily at low tide to remove Enteromorpha sp. that had accumulated. Trays were retrieved $72 \mathrm{~h}$ after deployment and contents gently rinsed on a $0.5 \mathrm{~mm}$ screen. Samples were preserved in $10 \%$ formalin, transferred to $70 \% \mathrm{EtOH}$ 3 d later, and sorted under a dissecting scope for ghost shrimp postlarvae. Shrimp CL was measured to the nearest $0.1 \mathrm{~mm}$ with an ocular micrometer. Since the lip of each tray stood $9 \mathrm{~cm}$ above the tideflat, shrimp were assumed to have settled from the water column rather than via bedload transport (Levin 1984, Eggleston \& Armstrong 1995). Number of postlarvae was analyzed as the response variable in a 2-way randomized block ANOVA model with substrate (shell vs mud) and cage (open vs cage vs control cage) as factors, and distance from the subtidal channel $(50,65,80,95$, and $110 \mathrm{~m}$ ) as the blocking factor There was no replication of treatments within blocks. Assumptions of normality and homogeneity of variance were met upon a $\log (x+1)$ transformation of the raw data $(p>0.9$, Cochran's $C$ test).

Settlement (laboratory). An experiment was also conducted in $401(50 \mathrm{~cm} \times 25 \mathrm{~cm} \times 35 \mathrm{~cm}$ height $)$ still water aquaria to test whether shrimp postlarvae display a preference for shell or mud habitats. Although settlement patterns result from the interaction between behavior and tidal flow across different habitats, this experiment was conducted to examine the behavioral component of settlement and to complement the field study. A $0.5 \mathrm{~mm}$ mesh neuston net was used to collect postlarvae in a night flood plankton tow during the full moon tide series of August 1993. Postlarvae were placed in an aerated aquarium filled with seawater maintained at 15 to $16^{\circ} \mathrm{C}$ and were held no longer than $2 \mathrm{~d}$ before use in an experimental trial. A subsample of shrimp was measured for carapace length $(\bar{X}=1.16 \mathrm{~mm}$ $\mathrm{CL}, \mathrm{SD}=0.07$, range 1.0 to $1.3 \mathrm{~mm} \mathrm{CL}, \mathrm{n}=16$ ). Aquaria were filled with $5 \mathrm{~cm}$ of sieved mud $(0.5 \mathrm{~mm}$ mesh) and partitioned into 2 equal compartments using a $5 \mathrm{~cm}$ tall wooden divider that prevented postlarvae from burrowing from one habitat into the other after selecting a particular substrate. A single layer of oyster shell covering approximately $95 \%$ of the available surface area was randomly assigned to one half of the tank 
Aquaria were filled with $15 \mathrm{~cm}$ of unfiltered seawater from the estuary and maintained at 15 to $16^{\circ} \mathrm{C} . \mathrm{A} 10 \mathrm{~cm}$ wide wooden platform was centered in each tank and submerged to elevate a $175 \mathrm{ml}$ Pyrex bowl containing 10 postlarvae in seawater. Each bowl was covered with a plexiglass plate to ensure that postlarvae did not escape upon submersion. After 15 min, plates were carefully removed to allow postlarvae to swim up and out of the bowls to select a habitat. At the end of $18 \mathrm{~h}$ ( $8 \mathrm{~h}$ light, $10 \mathrm{~h}$ dark), the number of postlarvae burrowed in mud and shell habitats, as well as the number remaining in the bowl or water column were recorded upon rinsing the water and substrate from each half of the tank through a $0.5 \mathrm{~mm}$ screen. The null hypothesis of no preference for either habitat was tested with a paired $t$-test $(n=23$ ).

Predation by YOY Dungeness crabs. The density of YOY Dungeness crabs was quantified at Pacman in $1.00 \%$ epibenthic shell within the shell plot and in the mud control plot in July and August, 1992, using the methodology described above in 'post-treatment YOY shrimp density' ( $n=12$ from each habitat). Crab carapace width (CW) was measured and crabs were grouped with respect to instar size.

We then examined the predator-prey interaction between YOY Dungeness crabs and shrimp in epibenthic shell to assess whether crabs forage on shrimp and to quantify prey consumption predator ${ }^{-1}$ as a function of 4 densities of shrimp. Due to limited prey densities and replicated trials, we did not attempt to identify the form of the functional response (i.e. type II or III; Holling 1959) as has been done in similar experiments with benthic decapod crustaceans (Lipcius \& Hines 1986. Sponaugle \& Lawton 1990, Eggleston et al. 1992). Assuming that ghost shrimp are prey for YOY Dungeness crabs, postlarval shrimp that successfully settle and establish burrows in shell habitat risk predation by crabs residing in the shell. We chose not to conduct identical experiments in mud because (1) YOY crabs occupy shell habitat at relatively high densities but rarely are found on unvegetated mudflats (Armstrong et al. 1992), and (2) crabs presumably emigrate from shell. plots directly to subtidal channels when they reach larger instar sizes (Dumbauld et al. 1993, Iribarne et al. 1994).

Juvenile shrimp (1.8 to $2.5 \mathrm{~mm}$ CL) were collected from the intertidal in August 1993 and placed in aerated aquaria with sediment and unfiltered estuarine seawater Crabs were collected by beam trawl (Gunderson \& Ellis 1986) from subtidal channels in the bay, placed in aerated aquaria with sediment and shell, and fed ad libitum with clams Cryptomya californica and juvenile English sole Pleuronectes vetulus. Crabs ranged from 21.6 to $28.1 \mathrm{~mm}$ CW (J5 and J6 instars) in experimental trials and did not differ significantly with various treatments of prey density (1-way ANOVA; $F=1.24, \mathrm{~d} f=3,36, \mathrm{p}=0.31$ ). Prior to feeding trials, crabs were checked for the presence of all pereopods, placed in isolation chambers $(5 \mathrm{~cm} \times 5 \mathrm{~cm})$, and starved for $48 \mathrm{~h}$. Individual shrimp and crabs were used only once in an experimental trial.

Forty-liter aquaria were filled with $5 \mathrm{~cm}$ of sieved mud ( $0.5 \mathrm{~mm}$ mesh) and $12 \mathrm{~cm}$ of unfiltered estuarine seawater. A $20 \mathrm{~cm}$ tall wooden divider with foam edges was placed in the center of each tank, reducing the experimental area to $0.06 \mathrm{~m}^{2}(0.25 \mathrm{~m} \times 0.25 \mathrm{~m})$. Aquaria were aerated, and water temperature was maintained at 15 to $16^{\circ} \mathrm{C}$ during all trials. Four experimental shrimp densities of $1,2,4$, and 12 shrimp $0.06 \mathrm{~m}^{-2}$ were used spanning the range of low to high densities of YOY shrimp (16 to 192 shrimp m m $^{-2}$ ) sampled in the control plot at Pacman. Control trials without a crab predator were also performed at the highest shrimp density to measure recovery efficiency of prey and estimate mortality due to handling The physical layout consisted of 24 experimental units (12 partitioned aquaria): 20 feeding replicates and 4 control replicates with random interspersion of shrimp density treatments and controls (Underwood 1981). All treatment densities and the control density were replicated 10 times.

Shrimp exhibiting active pleopod movement were introduced into aquaria and allowed $24 \mathrm{~h}$ to establish burrows. Most shrimp immediately swam to the bottom of the tank and tested the substrate with their pereopods. Individuals were replaced. if they had not constructed a burrow within $4 \mathrm{~h}$. This was necessary in only 7 trials where 1 individual was replaced in each trial. In contrast to predator-prey experiments with bivalves (Eggleston et al. 1992), we were unable to control for possible edge effects (i.e. crabs potentially consuming more or less shrimp near the periphery of the tank) since shrimp are highly mobile. In an earlier experimental trial, we determined that $36 \%$ (SD $=$ $24 \%, \mathrm{n}=28$ ) of burrow openings were within $1 \mathrm{~cm}$ of the tank wall; however, this does not necessarily indicate the position of the shrimp since burrows extend horizontally and typically have more than one opening. The day after shrimp were introduced into a tank, a single layer of oyster shell was placed on the sediment surface to simulate the structure of the shell plot. Feeding trials commenced upon the addition of a single J5 or J6 intermolt Dungeness crab and ended upon removal of the crab 24 h later. This density is equivalent to 16 crabs $\mathrm{m}^{-2}$, which was close to the overall mean field density in August 1992 (see Fig. 8). Tank water and substrate were rinsed on a $0.5 \mathrm{~mm}$. mesh screen and sorted for YOY shrimp.

Consumption rates (no. shrimp eaten $\mathrm{crab}^{-1} 24 \mathrm{~h}^{-1}$ ) and proportional mortality [(no. shrimp eaten) (no. 
shrimp present) ${ }^{-1} \mathrm{crab}^{-1} 24 \mathrm{~h}^{-1}$ ] were analyzed as a function of shrimp density with a 1-way ANOVA model. Consumption rates were $\log (x+1)$ transformed and proportional mortalities were arc-sine square-root transformed to meet assumptions of normality and homogeneity of variance (Underwood 1981). Despite the transformation, however, consumption rate variances remained heteroscedastic ( $p=0.02$, Cochran's $C$ test). Other transformations were similarly ineffective. Hence, hypotheses regarding the effects of shrimp density on consumption rates were rejected at an alpha value lower than the $\mathrm{p}$ value of the test for homogeneity of variance (i.e. $\mathrm{p}=0.01$; Underwood 1981) Tukey's multiple comparison test (Day \& Quinn 1989) was used to reveal differences between treatment means also at $\alpha=0.01$.

\section{RESULTS}

\section{Pre-treatment shrimp density}

Shrimp retained by the $3 \mathrm{~mm}$ mesh ranged in size from 2.3 to $20.1 \mathrm{~mm} \mathrm{CL}$. There was a significant difference in shrimp abundance prior to shell plot construction ( $t$-test: $t=3.16$, df $=4, \mathrm{p}<0.05$ ). Mean number of shrimp was approximately 2 times higher in the control plot $\left(\bar{x}=50.9\right.$ shrimp $\left.\mathrm{m}^{-2}, \mathrm{SD}=19.2\right)$ than in the designated shell plot $(\bar{x}=22.3$ shrimp $m \div$ SD $=6.7)$.

\section{Post-treatment YOY shrimp density}

Prior to conducting statistical analyses, individuals were assigned a settlement year class based on visual assessment of size frequency histograms for June, July, and August 1992 (Fig. 2). Shrimp collected in June and July 1992 were assigned to the 1991 year class (Fig. 2). Mean carapace length of individuals from the $1991 \mathrm{YC}$ increased from $3.5 \mathrm{~mm}$ in June to $5.4 \mathrm{~mm}$ in August (Fig. 3). By August 1992, settlement of YOY shrimp was underway. Mean carapace length of YOY shrimp was $2.1 \mathrm{~mm}$ in August 1992 and only increased to $3.2 \mathrm{~mm}$ by June 1993 (Fig. 3), reflecting both slow growth over the fall and winter (Dumbauld et al. 1996) and incorporation of additional cohorts of postlarval shrimp that settled after August which effectively reduced mean size.

The presence of 2 age classes of shrimp was apparent in depth distribution samples collected in August 1992: YOY individuals (1992 YC) ranged in size from 1.1 to $3.3 \mathrm{~mm} \mathrm{CL}$, and individuals from the $1991 \mathrm{YC}$ ranged from 3.9 to $6.9 \mathrm{~mm}$ CL. These size ranges are in agreement with those used to distinguish 1991 and 1992 year classes for analyses of recruit densities (see
Fig. 2. Neotrypaea californiensis. Size frequency histograms of juvenile ghost shrimp collected from core samples at Pacman in June, July, and August 1992 Measurements of shrimp from the shell and control plots were pooled by month. Individuals collected in June and July had settled the previous year (1991 YC). By August, 2 year classes of shrimp were present in samples: 1992 (YOY) as well as 1991
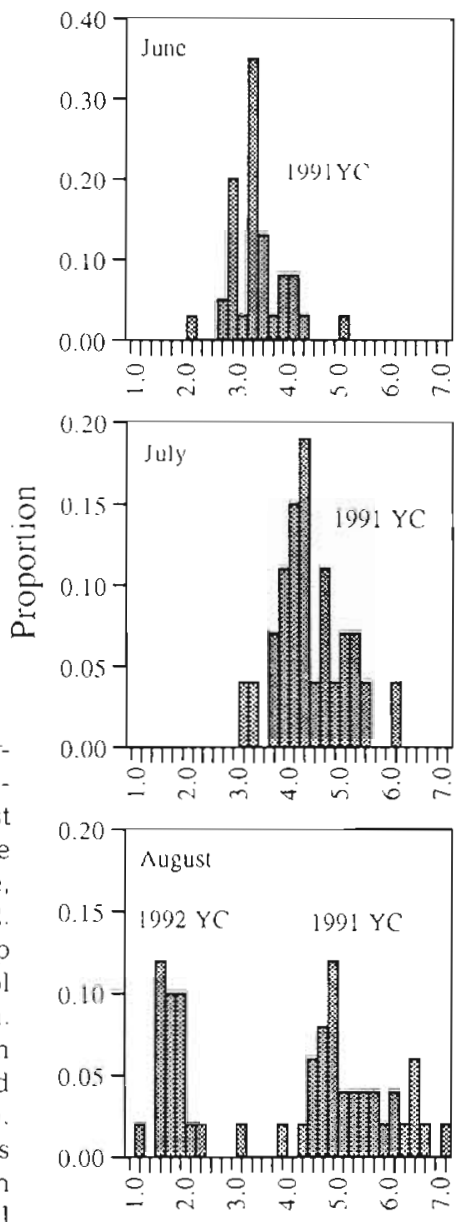

Carapace Length ( $\mathrm{mm}$ )

Fig. 2). Seventy percent of YOY individuals were collected in the top $5 \mathrm{~cm}$ of sediment, and another $23 \%$ were collected at 5 to $10 \mathrm{~cm}$ depth (Fig. 4) In contrast, only $16 \%$ of 1 yr old shrimp were collected in the top $10 \mathrm{~cm}$, the remainder distributed almost evenly between 10 to 15 and 15 to $20 \mathrm{~cm}$ depth (Fig. 4).

The difference in shrimp abundance between plots prior to shell application (see section above) dictated that we use the odd's ratio test (modified for unequal sample sizes) to test for differences in YOY shrimp densities between habitats. Both mean pre-treatment shrimp densities and mean post-treatment YOY densities were used in calculating test statistics. We chose a priori to test hypotheses of no difference in YOY density between substrate types $\left(\mathrm{H}_{0}: D=1\right.$ versus $\left.H_{\mathrm{c}} . D \neq 1\right)$ at $\alpha=0.01$ since we could only test combinations of 2 habitats at a time. In August 1992, density of YOY shrimp was significantly lower in epibenthic shell than in mud $(D=0$, $\mathrm{p}<0.01$; Fig. 5A). YOY shrimp were absent in the shell plot but present in the control plot (see Table 1, uncorrected mean YOY densities). In June 1993, density of YOY shrimp (1992 YC) was significantly lower in 


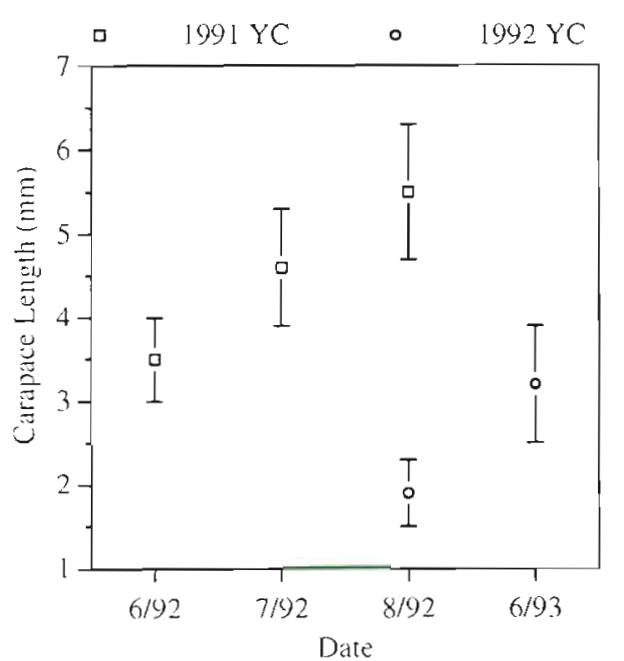

Fig. 3. Neotrypaea calforniensis. Mean carapace lengths (mm) of ghost shrimp from core samples at Pacman, grouped according to the year they settled (1991 vs 1992). Measurements of shrimp from all substrates (epibenthic shell, subsurface shell, and bare mud) were combined to estimate mean size by sampling month

epibenthic shell than in mud $(D=0.14, \mathrm{p}<0.01)$, and significantly lower in epibenthic shell than in 'subsurface shell' $(D=0.10, \mathrm{p}<0.01$; Table 1, Fig. 5B). There was no difference in shrimp density between mud and 'subsurface shell' $(D=1.47, \mathrm{p}>0.01$; Table 1, Fig. 5B)

\section{Settlement (field)}

Shrimp recovered from settlement trays placed on an unvegetated tideflat at Campbell Slough (Fig. 1) during August 1993 ranged in size from 0.9 to $9.3 \mathrm{~mm} \mathrm{CL}$. Based on the size frequency of shrimp collected in the trays (Fig. 6) and on measurements of a random sample of postlarvae collected during a plankton tow [see 'Materials and methods: Settlement (laboratory)'], only shrimp that ranged in size from 0.9 to $1.3 \mathrm{~mm}$ CL were considered 'settlers' and included in statistical analyses. Shrimp $\geq 1.4 \mathrm{~mm} \mathrm{CL}$ accounted for only $7.6 \%$ of all shrimp in settlement trays.

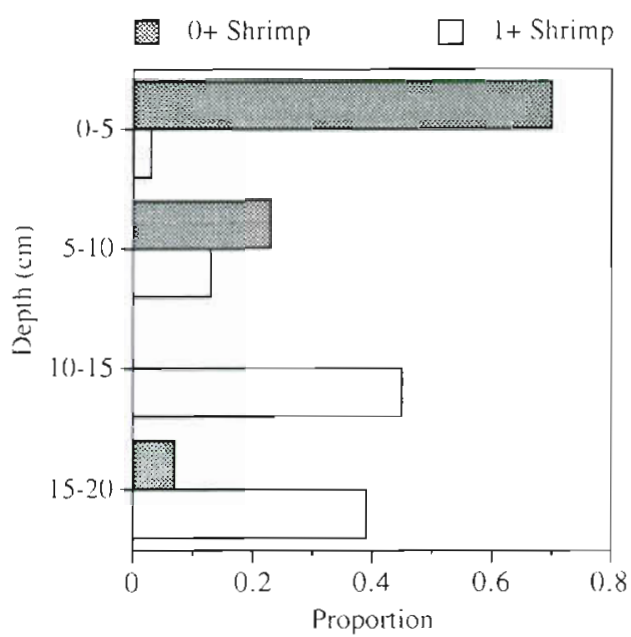

Fig. 4. Neotrypaea californiensis. Vertical distribution of ghost shrimp from 0 to $20 \mathrm{~cm}$ depth, sampled August 1992 in the Pacman control plot. The proportion of shrimp at each depth interval is plotted according to year class (YC). Ind.viduals from the 1992 YC $(0+)$ ranged in size from 1.1 to $3.3 \mathrm{~mm} \mathrm{CL}$, and individuals from the $1991 \mathrm{YC}(1+)$ ranged in size from 3.9 to $6.9 \mathrm{~mm} \mathrm{CL}$

We used a 2-way randomized block ANOVA model to test for interactions between block, substrate, and cage factors and for significance of main treatment effects. No first-order interactions were significant, thus allowing direct conclusions of the main effects (Table 2). Due to the lack of replication within blocks, we were unable to test for a second-order interaction; however, we assumed that the interaction between block, substrate, and cage treatment was non-significant as well, based upon visual assessment of graphed data. Counts of shrimp ranged from 0 to 58 postlarvae $\left(0.25 \mathrm{~m}^{2}\right)$. Postlarval densities differed significantly by substrate but not by block or cage treatment (Table 2). Mean numbers of postlarvae settling in shell were significantly lower than in mud (Table 2, Fig. 7). The blocking factor was not significant indicating that distance to the subtidal channel accounted for little of the variation in postlarval densities between treatments. Settlement densities tended to be higher in open trays than in either trays with cages or control cages (Fig. 7);

Table 1. Neotrypnea califormensis. Mean post-treatment densities of YOY ghost shrimp $\mathrm{m}^{-2}$ (standard deviations given in parentheses) in epibenthic shell, 'subsurface shell', and mud (control) habitats after shell plot construction. Uncorrected YOY values (actual densities) are given as well as corrected values (odd's ratio $D$ value). Densities were corrected using an odd's ratio design given a significant difference in pre-treatment shrimp density between the shell and control plots (see text and Fig. 5 legend for details)

\begin{tabular}{|c|c|c|c|c|c|}
\hline & \multicolumn{2}{|c|}{ August $1992(n=12)$} & \multicolumn{3}{|c|}{ June $1993(n=1.0)$} \\
\hline & Epibenthre shell & N.Tud & Epibenthic shell & Subsurface shell & Mud \\
\hline Uncorrected value (actual density) & 0 & $40.6(38.0)$ & $8.2(17.2)$ & $85.6(59.8)$ & $132.4(86.7)$ \\
\hline Corrected value (odd's ratio ' $D$ ') & 0 & $0.8(0.3)$ & $0.4(0.3)$ & $3.8(1.0)$ & $2.6(0.7)$ \\
\hline
\end{tabular}



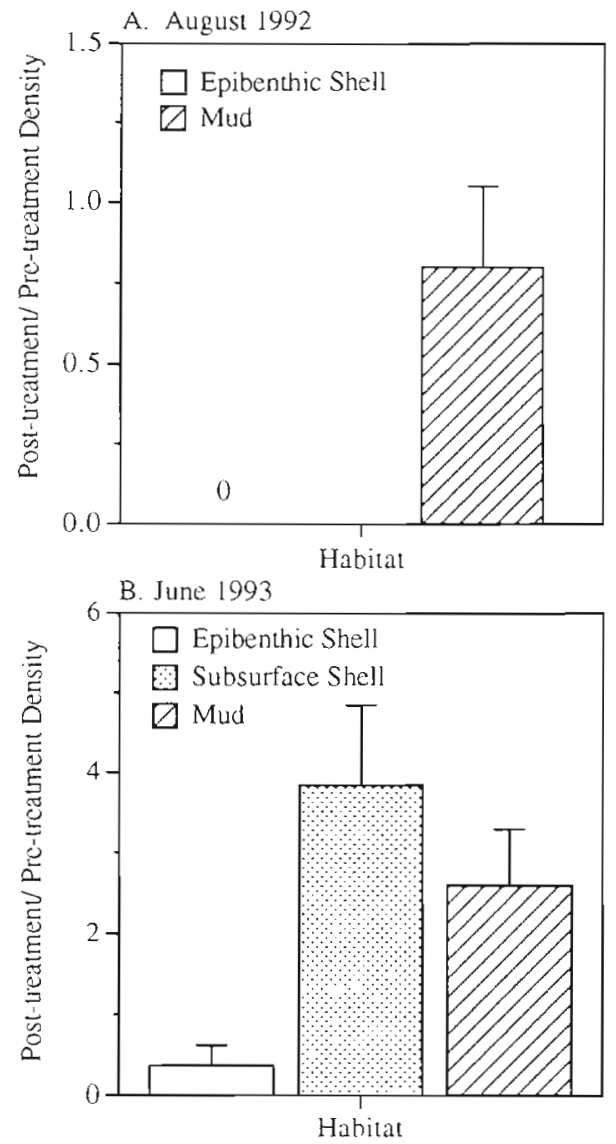

Fig. 5. Neotrypaea californiensis. Comparison of relative densities of YOY ghost shrimp $\mathrm{m}^{-2}$ with respect to substrate type at Pacman. Mean post-treatment shrimp density (i.e. YOY density) was divided by mean pre-treatment shrimp density (i.e. mean local density prior to shell plot construction) for each habitat to correct for inherent differences in shrimp density between shell and control plots prior to shell deposition. (A) August 1992; newly settled shrimp were sampled in epibenthic shell and mud. (B) June 1993; YOY shrimp (1992 year class) were sampled in epibenthic shell, 'subsurface shell', and mud. Vertical bars are $1 \mathrm{SD}$

however, the difference was not statistically significant (Table 2). Few crabs were recovered from settlement trays: one Dungeness crab (31.5 $\mathrm{mm} \mathrm{CW}$ ) and a few small shore crabs Hemigrapsus oregonensis (generally $\leq 5.0 \mathrm{~mm} \mathrm{CW}$ ).

\section{Settlement (laboratory)}

Over $96 \%$ of shrimp postlarvae introduced into laboratory aquaria selected a substrate within the $18 \mathrm{~h}$ experimental period. Only $8(<4 \%)$ remained in the 'introduction' bowl or swimming in the water column. Recovery efficiency was $100 \%$, and survival appeared to be $100 \%$ as well based on pleopod movement or

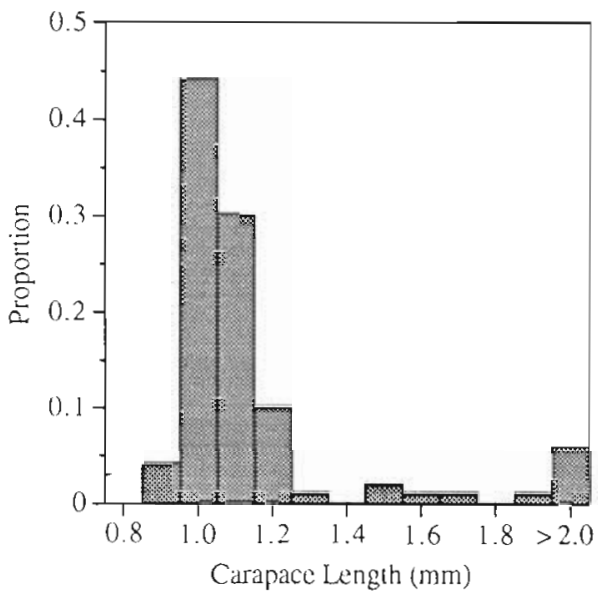

Fig. 6. Neotrypaea californiensis. Size frequency of ghost shrimp recovered from trays set out at Campbell Slough in August 1993 to measure settlement of postlarvae into shell and mud substrates. Shrimp $\leq 1.3 \mathrm{~mm}$ CL were included in calculations of mean densities

translucent body coloration (the few postlarvae that died in the holding tank were opaque). Although the mean proportion of postlarvae settling in shell $(\bar{x}=0.42$, $\mathrm{SD}=0.25)$ was lower than in mud $(\bar{x}=0.58, \mathrm{SD}=0.25)$, the trend was not significant (paired t-test: $t=1.67$, $\mathrm{df}=22, \mathrm{p}=0.11$ ). Postlarval shrimp selecting shell substrate established burrow holes along the edges of the tank and in crevices between individual shells.

\section{Predation by YOY Dungeness crabs}

The overall mean density of YOY Dungeness crabs in epibenthic shell at Pacman was $53.3 \mathrm{crabs}^{-2}$ in July 1992, and J3 and J4 instars (12.5 to $19.4 \mathrm{~mm} \mathrm{CW}$ ) were the most prevalent size classes (Fig. 8). In August,

Table 2. Neotrypnea californiensis. Results of a 2-way randomized block ANOVA on log $(x+1)$ transformed densities of ghost shrimp postlarvae (0.9 to $1.3 \mathrm{~mm} \mathrm{CL})$ showing the effect of blocks (relative proximity to a nearby subtidal channel), substrate (shell vs mud) and cage treatment (open vs cage vs control cage) on settlement patterns. Settlement into $0.25 \mathrm{~m}^{2}$ trays was measured over a $72 \mathrm{~h}$ period during the new moon spring-tide series of August, 1993. $p<0.05$

\begin{tabular}{|lccccc|}
\hline Source of variation & SS & df & MS & $F$ & p \\
\hline Block & 0.04 & 4 & 0.01 & 0.07 & 0.99 \\
Substrate & 1.15 & 1 & 1.15 & 7.59 & 0.02 \\
Cage treatment & 1.18 & 2 & 0.59 & 3.89 & 0.07 \\
Block $\times$ substrate & 0.63 & 4 & 0.16 & 1.04 & 0.45 \\
Block $\times$ cage & 1.12 & 8 & 0.14 & 0.92 & 0.55 \\
Substrate $\times$ cage & 0.36 & 2 & 0.18 & 1.17 & 0.36 \\
Error & 1.21 & 8 & 0.15 & & \\
\hline
\end{tabular}




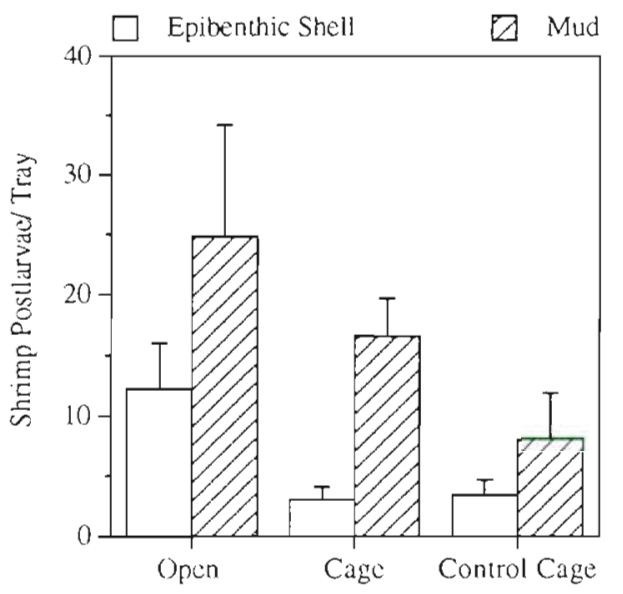

Fig. 7. Neotrypaea californiensis. Results of the August 1993 field experiment at Campbell Slough comparing settlement of ghost shrimp postlarvae as a function of substrate (epibenthic shell and mud) and cage structure (open (no cage), cage, and control cage]. Values are mean densities of postlarvae tray ${ }^{-1}$ $72 \mathrm{~h}^{-1}$ Vertical bars are $1 \mathrm{SE}$

mean density declined to $15.0 \mathrm{crabs}^{-2}$, and $\mathrm{J} 4$ and $\mathrm{J} 5$ instars ( 15.5 to $26.0 \mathrm{~mm} \mathrm{CW}$ ) dominated the size composition of crabs (Fig. 8). No crabs were found in samples taken in the control plot in July and August.

In the laboratory predator-prey interaction experiment, recovery efficiency of shrimp in control tanks was $100 \%$, and natural mortality due to handling was $6.2 \%$. Consumption rates differed significantly by prey density ( 1 -way ANOVA $i f=10.66, \mathrm{df}=3,36, p<0.01$ ). Consumption rates were greater at the highest prey density ( 3.4 shrimp $\mathrm{crab}^{-1} 24 \mathrm{~h}^{-1}$ ) than at any of the

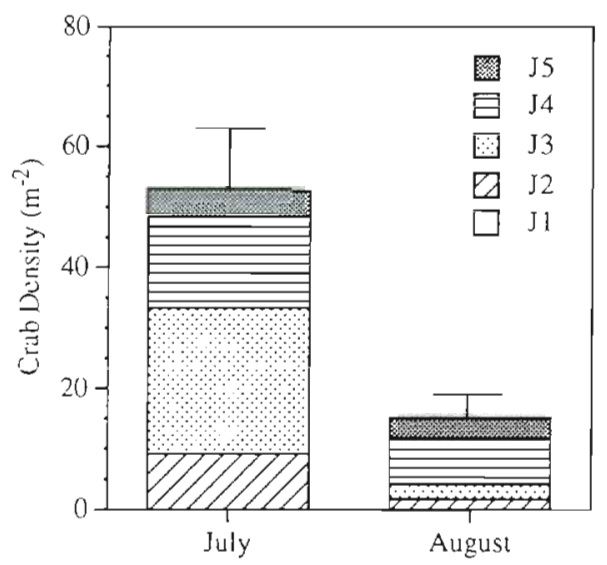

Fig. 8. Cancer magister. Dungeness crab density and instar composition in the Pacman shell plot, July and August 1992. Vertical bars are 1 SE for the total mean density, all instars combined. No crabs were recovered from samples taken in the mud control plot ( $\mathrm{n}=12 \mathrm{in}$ each habitat). The sequential decline in density between J3 and J4 instars is believed to be an indication of emigration of larger instars from the shell plot to the subtidal
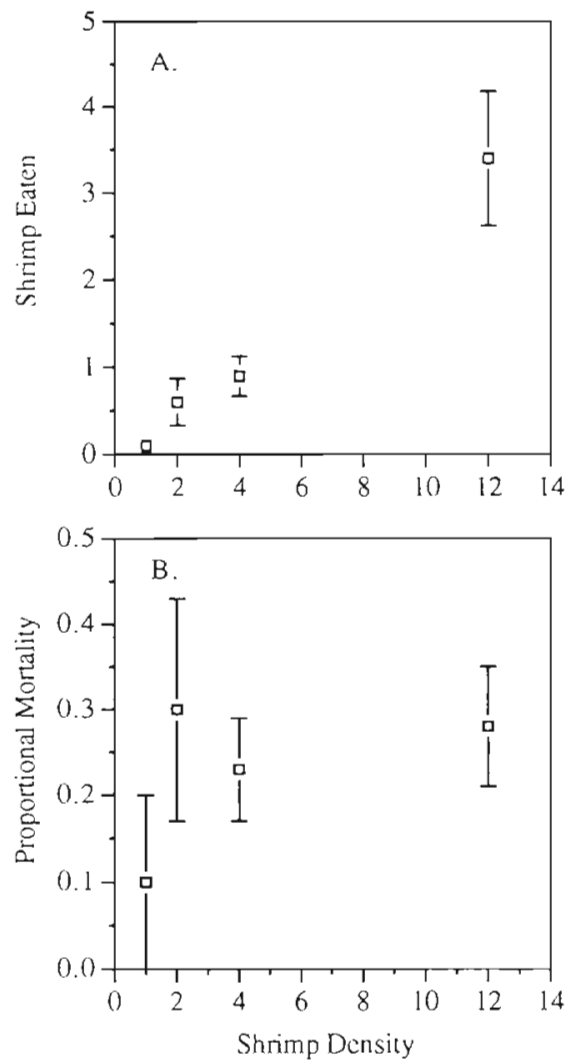

Fig. 9. Cancer magister/Neotrypaea californiensis. Results of YOY Dungeness crab predation experiments on 4 densities of YOY ghost shrimp tank ${ }^{-1}\left(0.06 \mathrm{~m}^{2}\right)$. Mean values $( \pm 1 \mathrm{SE}$ ) are plotted for (A) consumption rate (no. shrimp eaten crab ${ }^{-1}$ $24 \mathrm{~h}^{-1}$ ) and (B) proportional mortality [(no. shrimp eaten) (no. shrimp present $\left.\}^{-1} \mathrm{crab}^{-1} 24 \mathrm{~h}^{-1}\right]$

lower prey densities $\left(0.1\right.$ to 0.9 shrimp $\mathrm{crab}^{-1} 24 \mathrm{~h}^{-1}$; Fig. 9A). Proportional mortalities, however, did not differ significantly with prey density $(F=1.14$, df $=$ $3,36, p=0.34$; Fig. 9B, power $\approx 0.10$ ). Despite attempts to standardize hunger levels, there was considerable variation in prey consumption within treatment densities.

\section{DISCUSSION}

Results of our examination of the distribution of YOY ghost shrimp in intertidal shell and mud substrate at the Pacman mitigation site support conclusions of other studies which suggest that some complex habitats may limit the distribution of Neotrypaea californiensis. Dumbauld (1994) found a negative effect of live oysters on recruitment success of $N$. californiensis compared to other treatments which included bare mud. Brenchley (1982) demonstrated that mean burial time increased significantly for $N$. californiensis in 
root-rhizome and animal tube mats compared to preburrowed bare sediments, and in the majority of laboratory trials shrimp were unable to establish a burrow at all. Field surveys have been consistent with Brenchley's (1982) findings, noting the abrupt decline and low densities of $N$. californiensis burrows in Zostera marina beds compared to adjacent intertidal mudflats (Swinbanks \& Murray 1981, Swinbanks \& Luternauer 1987), although it is unclear how these patterns were initially established.

Similarly, dense application of epibenthic bivalve shell to the intertidal mudflat effectively reduced recruitment of YOY Neotrypaea californiensis at Pacman. Newly settled shrimp were absent in epibenthic shell habitat during initial recruitment of the 1992 year class in August 1992. In June 1993, the same trend was observed with lower densities of YOY shrimp in epibenthic shell than in contiguous patches of mud overlying shell ('subsurface shell') as well as in bare mud. In contrast, there was no difference in density between 'subsurface shell' and bare mud habitats. Although inferences in this study are limited to Pacman since treatments were not replicated, similar patterns of YOY ghost shrimp abundance in epibenthic shell, 'subsurface shell', and bare mud have been observed in small-scale experiments in Willapa Bay, Washington (K. Feldman unpubl. data).

Habitat-specific recruitment success results from complex interactions among numerous physical and biological parameters which influence larval supply, larval substrate selection at the time of settlement, and survival of settlers. Larval supply to estuarine locations is influenced by physical processes such as tidal currents (Alldredge \& Hamner 1980) and wind-driven surface currents (Eggleston \& Armstrong 1995), although larval behavior can alter horizontal transport via depth regulation within the water column (e.g. review by Sulkin 1984, Tankersley et al. 1995) Upon arrival at a site, larvae may accept or reject a habitat based on the presence or absence of positive and negative cues (Woodin 1991). Substrate selection may be primarily a passive process whereby settlement is determined largely by benthic boundary layer flow processes in the case of weaker swimming larvae or more of an active process in the case of stronger swimming larvae (Butman 1987). Although larval settlement can contribute significantly to spatial and temporal patterns of distribution and abundance (Bertness et al. 1992), variation in settlement densities can be masked by post-settlement processes such as differential predation risk and movement among habitats (Keough \& Downes 1982. Connell 1985). Recently, however, marine ecologists have placed greater emphasis on assessing the relative contribution of pre-settlement and post-settlement components of recruitment to gain a greater understanding of benthic population structure and dynamics (e.g. Stoner 1990, Eggleston \& Armstrong 1995)

Results of our experiments suggest that postlarval substrate selection was a key determinant of habitatspecific recruitment success of Neotrypaea californiensis in this study. Ghost shrimp postlarvae exhibited differential settlement between mud and shell habitats in the $72 \mathrm{~h}$ field experiment. Under natural tidal flows, 2 to 5 times more postlarvae were recovered from mud trays than shell trays placed on the bare mudflat. The laboratory experiment showed a similar trend of higher settlement in bare mud than shell, although the difference was not statistically significant. The discrepancy between experimental results may be due to the role of hydrodynamics in situ on settlement behavior or differences in the thickness of the shell layer in each experiment ( 2 to 3 shells thick in the field experiment versus 1 shell thick in the laboratory experiment)

Two potential artifacts of the field design that could have affected postlarval settlement patterns are the dissimilarity in spatial scale between the small substrate-filled trays and the surrounding mudflat and the effect of placing trays directly on the mudflat as opposed to burying them flush with the sediment surface. These artifacts were addressed in a study by Eggleston \& Armstrong (1995) in which they quantified Dungeness crab settlement in $0.25 \mathrm{~m}^{2}$ trays of shell and mud at Pacman and South Channel mitigation and control plots. First, the disruption in flow resulting from a change in physical structure and spatial scale (e.g. flow over an expansive mudflat to flow over a small patch of epibenthic shell) might have produced an artificial settlement pattern. However, Eggleston \& Armstrong (1995) found no difference in the number of crab megalopae recovered from shell and mud trays placed on bare mudflats versus shell and mud trays placed well within large shell plots; crab megalopae selected shell over mud regardless of where the trays were located (e.g. $0.25 \mathrm{~m}^{2}$ of shell placed in 4 ha of shell or 4 ha of mud). Second, with respect to the issue of raised trays altering settlement patterns, Eggleston \& Armstrong (1995) also found no difference in the number of crab megalopae recovered from shell and mud trays placed on top of the sediment in shell mitigation plots and those buried flush with the sediment surface. Based on these results, we suggest that patterns of postlarval settlement in this study were the result of differential settlement between substrate types rather than experimental artifacts. Nevertheless, ghost shrimp are different organisms, and shrimp postlarvae may respond to benthic boundary layer conditions differently than Dungeness crab megalopae.

In addition to postlarval substrate selection. Dungeness crab predation on settling ghost shrimp may have 
further accentuated the difference in shrimp densities between shell and mud habitats. Crabs were present in the shell plot at Pacman and consumed shrimp in the laboratory. YOY Dungeness crabs occupied shell habitat at Pacman in July and August 1992, but were absent from the control plot during shrimp settlement (Fig. 8). In the laboratory experiment, crabs successfully excavated and preyed on burrowed shrimp in shell habitat. While crabs consumed greater numbers of shrimp as prey density increased, the lack of an increase in proportional mortality over the range of prey densities suggests that YOY crabs alone could not be responsible for patterns of shrimp recruitment. However, differential settlement, possibly modified by Dungeness crab predation, could explain much of the variation in recruitment success of ghost shrimp between shell and mud. Even if proportional mortality was constant over a range of prey densities, YOY crabs could still find and consume shrimp settling in low densities in the shell plot. For example, based on an average density of 32 shrimp $\mathrm{m}^{-2}$ (corresponding to 2 shrimp tank ${ }^{-1}$ in the laboratory experiment) and a consumption rate of 0.6 shrimp $\mathrm{crab}^{-1} \mathrm{~d}^{-1}$, a density of 15 crabs $\mathrm{m}^{-2}$ could potentially consume 9 shrimp $\mathrm{m}^{-2}$ $\mathrm{d}^{-1}$. Hence, the few postlarval shrimp that successfully settled in epibenthic shell could have been eaten by YOY crabs over time, helping produce the recruitment pattern we observed at Pacman. While this is the first report of YOY crab predation on YOY ghost shrimp as far as we are aware, Stevens et al. (1982) documented the presence of ghost shrimp in the stomachs of subadult Dungeness crabs, and Posey (1986b) found that larger juvenile Dungeness crabs (generally $>4 \mathrm{~cm}, \mathrm{M}$. Posey pers. comm.) attacked and consumed juvenile ghost shrimp in aquaria containing sediment.

Although laboratory experiments are instrumental in examining predator-prey interactions, other variables could affect Dungeness crab foraging patterns and predation on YOY shrimp in natural habitats. First, gammarid amphipods, bivalves, polychaetes, and conspecific YOY crabs are abundant in epibenthic shell throughout most of the summer and provide crabs with alternative prey resources (Armstrong et al. 1992, Fernandez et al. 1993a, Williams 1994). However, recent studies have shown that juvenile ghost shrimp were the second most common prey item consumed by $\mathrm{J} 2$ and J4 crabs among those taxa listed above and accounted for the greatest amount of biomass (ash-free dry weight, AFDW) in their diets ( $E$. Visser, University of Washington, unpubl. data). Second, temporal residency patterns by YOY crabs in shell habitat may also influence the extent to which settling shrimp are vulnerable to crab predation. Crab density declines throughout the summer due to natural mortality and emigration of older instars to subtidal channels (Dum- bauld et al. 1993, Iribarne et al. 1994, Eggleston \& Armstrong 1995). Since ghost shrimp settlement generally extends from August into October, later settling shrimp may encounter fewer but larger crabs than earlier settlers. Finally, burial depth provides refuge from epibenthic predators (Blundon \& Kennedy 1982, Barshaw \& Able 1990). However, $70 \%$ of newly settled shrimp occupied the top $5 \mathrm{~cm}$ of sediment (Fig. 4); thus, they may be available for consumption by crabs which regularly forage to that depth.

Unfortunately, we were unable to discern the impact of Dungeness crab predation in the field settlement experiment. Densities of shrimp postlarvae in shell habitat trays with full cages and control cages were similar (Fig. 7), and few crabs were recovered in shell trays. Although crabs could have immigrated into shell treatments and then emigrated before recovering the experiment, it is possible that crabs did not encounter the substrate-filled trays on the intertidal. Dungeness crabs settle on mudflats along Campbell Siough (Iribarne et al. 1995), but in the absence of suitable refuge, densities quickly decline due to predation. Our experiment was conducted in August, several months after peak crab settlement, on a broad ghost shrimp bed with little epibenthic structure. Thus, there may not have been a local population of crabs to potentially colonize settlement trays. The presence of YOY Dungeness crabs has been documented in subtidal channels along Campbel.. Slough (Armstrong et al. 1992), but crabs may not have left the subtidal to risk foraging on the mudflats. The experiment was conducted at Campbell Slough because densities of ghost shrimp historically have been high at that site [due to hydrodynamics or some other factor(s)], thereby increasing the chance of high numbers of postlarvae settling in the trays. The same experiment conducted at Pacman in 1992 was unsuccessful because so few postlarvae settled over the $3 \mathrm{~d}$ duration. While we had no a priorj reason to assume that settlement behavior would differ between locations within the bay, it is possible that habitat preferences of settling ghost shrimp could have been affected by potential differences in the predator guilds between Campbell Slough and Pacman. Nevertheless, there was a significant difference in postlarval densities between the two substrate types regardless of whether YOY crabs or other predators were present, which is indicative of the negative effect of shell material on ghost shrimp settlement.

Although results of our experiments suggest that postlarval substrate selection was a key determinant of initial shrimp recruitment patterns, with possible modification by Dungeness crab predation, there are alternative explanations which are not mutually exclusive: (1) enhanced passive deposition of shrimp postlarvae to mud substrate ${ }_{i}(2)$ enhanced settlement and 
survival of YOY shrimp near adult conspecifics; (3) postsettlement movement of YOY shrimp; and (4) consumption of YOY shrimp by predators other than Dungeness crabs

First, settlement patterns could have resulted from differential passive deposition of shrimp to shell and mud habitats. We argue against passive deposition as the principal mechanism responsible for patterns of differential settlement, however, based on the results of the field experiment which contradict expected results under this hypothesis and on observations of postlarval swimming ability. First, under the passive deposition hypothesis, we would predict greater settlement of postlarvae in shell than in mud due to increased boundary layer shear stress over shell resulting in slower current speeds (Butman 1987, Wright et al. 1990). This prediction was supported in an experiment by Eckman (1983) in which settlement of fine sediment particles and passively dispersed fauna was significantly higher in moderate and dense protruding tube arrays than in the ambient, relatively uniform mudflat. In contrast, our results showed the opposite trend with significantly fewer postlarvae settling in shell than in mud. Second, benthic boundary-layer flow processes predominate in relatively weak swimmers often resulting in passive deposition to intertidal habitats (Eckman 1983, Hannan 1984, Butman et al. 1988, Snelgrove et al. 1993), whereas behavioral mechanisms play a greater role in relatively strong swimmers resulting in a greater degree of active choice in substrate selection (review by Meadows \& Campbell 1972, Crisp 1974, Botero \& Atema 1982, Herrnkind \& Butler 1986, Fernandez et al. 1994, Eggleston \& Armstrong 1995). Sustained directional swimming has been demonstrated for a number of decapod crustaceans under low (e.g. $<5 \mathrm{~cm} \mathrm{~s}^{-1}$; Luckenbach \& Orth 1992), moderate (e.g. 5 to $20 \mathrm{~cm} \mathrm{~s}^{-1}$; Calinski \& Lyons 1983, Cobb et al. 1989), and swift flows (e.g. 20 to $40 \mathrm{~cm} \mathrm{~s}^{-1}$; Fernandez et al. 1994). Although swimming behavior of ghost shrimp postlarvae under controlled flows is undescribed, observations in still water suggest that they are fairly strong swimmers $\left(\leq 5 \mathrm{~cm} \mathrm{~s}^{-1}\right.$; K. Feldman unpubl. data) using their pleopods to propel them forward. While ghost shrimp may be unable to maintain horizontal position in moderate to swift current flows, we hypothesize that under low flows associated with slack tides and within the viscous boundary layer, postlarvae are capable of exerting active habitat choice

Second, the presence of adult shrimp could have affected recruitment of YOY shrimp. Adults, for example, can facilitate recruitment of juveniles by modifying the substrate to make it more hospitable (Thrush et al. 1992). Tamaki \& ingole (1993) showed that Callianassa japonica larvae settle broadly, but post- settlement survival was higher in areas inhabited by adults, perhaps due to greater ease of burrowing in or oxygenation of reworked sediments. Recruitment data from Pacman and results of the settlement field experiment suggest, however, that conspecifics did not have a large effect on patterns of recruitment between shell and mud in this study. If conspecific density had influenced shrimp recruitment patterns, then most likely we would have observed similar YOY shrimp densities in epibenthic shell and 'subsurface shell' since both habitats were characterized by a single initial mean shrimp density in the pre-treatment shrimp assessment study. Instead, YOY shrimp density was significantly lower in epibenthic shell than in contiguous 'subsurface shell' patches. Thus, other factors that differed between the 2 habitats types, such as flow, structural complexity, food availability, and predator abundance, more likely affected postsettlement densities than the presence of adult conspecifics. In addition, the field settlement experiment was conducted on a homogenous expanse of mudflat at Campbell Slough where ambient YOY shrimp densities were similar within the area chosen for the study (K. Feldman unpubl. data). Accordingly, any ambient conspecific cue encountered by settling postlarvae would most likely have been similar across treatments, yet postlarval settlement into trays was significantly different between substrate types.

Third, epibenthic shell may have interfered with burrow maintenance and deposit feeding by postsettlement juveniles, forcing them to emigrate. Juvenile and adult migrations have been reported (Bird 1982, Posey 1986b, Harrison 1987), although reasons for and conditions of their occurrence have not been examined. In this study, raised settlement trays of both mud and shell were colonized by a few older YOY, juvenile, and adult shrimp $17.6 \%$ of individuals collected in trays were known to be immigrants), providing some evidence of movement either though active choice or bedload transport. Thus, post-settlement dispersal may play a role in establishment of recruitment patterns of YOY shrimp, but its importance in this study is unknown.

Finally, other predators, in addition to Dungeness crabs, could have limited the distribution of YOY shrimp in shell. Staghorn sculpin Leptocottus armatus have been shown to restrict the lower distribution of burrowing shrimp on unvegetated intertidal mudflats (Posey 1986b). While no studies have specifically examined whether staghorn sculpin restrict the densities of YOY shrimp in shell habitat, they prey on juvenile and adult shrimp in the vicinity of epibenthic shell substrate based on stomach content analyses of sculpins captured over COE mitigation plots (Williams 1994, Armstrong et al. 1995). Saddleback gunnels Pholis 
ornata, which reside within the shell habitat matrix, might prey on settling or post-settled shrimp, but Williams (1994) found no evidence of burrowing shrimp in their stomach contents. Glycerid polychaetes and nemertean worms, also associated with intertidal shell (Williams 1994), feed on small invertebrates and represent potential infaunal predators on YOY shrimp as well.

In summary, recruitment of YOY ghost shrimp was significantly reduced in the presence of epibenthic shell at the Pacman mitigation site. Results of our experiments suggest that larval habitat selection was responsible in part for the establishment of initial habitat-specific distribution patterns while predation by Dungeness crabs could have further enhanced the difference in post-settlement densities between epibenthic shell and mud substrates. These findings are encouraging with respect to the COE's efforts to mitigate loss of subadult crabs by increasing the amount of habitat for juvenile crabs. Where epibenthic shell can persist, YOY ghost shrimp establishment will likely be discouraged. However, it appears that even the relatively low densities of juvenile and adult shrimp occupying the area of shell deposition at Pacman contributed to the substantial loss of shell since much of the shell had sunk in the 3 mo prior to YOY ghost shrimp recruitment. These areas of 'subsurface shell' were readily colonized by YOY shrimp, and it is unknown whether shrimp that recruited to this configuration of stratified mud and shell eventually penetrated through the shell layer as they grew older, thereby contributing further to habitat degradation.

Although our findings are restricted to the mitigation. shell plot, studies are currently being conducted to test the effectiveness of applying epibenthic shell to intertidal oyster culture grounds in Washington coastal estuaries to hinder recruitment of burrowing shrimp Neotrypaea californiensis and Upogebia pugettensis (K. Feldman, B. Dumbauld \& D. Armstrong unpubl. data). Burrowing shrimp have an adverse effect on oysters, particularly settling oyster larvae and spat, by resuspending sediments and reducing the compaction of the sediment upon which oysters grow [Stevens 1929, Loosanoff \& Tommers 1948, Washington Department of Fisheries (WDF) 1970, Simenstad \& Fresh 1995]. Live oysters sink into the mud in areas populated by burrowing shrimp, similar to that observed for oyster shell at Pacman. Since 1963, the insecticide carbaryl (i.e. Sevin ${ }^{3}$ ) has been used to remove shrimp from intertidal oyster culture grounds in Washington (WDF 1970); however, carbaryl is also toxic to nontarget species including Dungeness crabs (Buchanan. et al. 1985) and does not discourage reinvasion by YOY ghost shrimp (Dumbauld et al. 1996). It is hoped that by studying the early life history of burrowing shrimp and mechanisms underlying their patterns of distribution in shell and mud substrates, we will gain a more comprehensive understanding of how these benthic habitats are structured and be better able to evaluate efforts to reduce recruitment of ghost shrimp on oyster culture grounds and intertidal shell plots designed to mitigate loss of fisheries resources through large-scale habitat manipulations

Acknowledgnments. We thank Greg Willams, Miriam Fernandez, Osiar Irıbarne, Bill Patton, Jo Linse, Leonard Feldman, Ward Ellis, Gretchen Frankenstein, Michael Herrle, Pam Jensen, Greg Jensen, and Jan Armstrong for theur help with field and laboratory work and for helpful discussions, and John Skalski tor statistical advice. We also thank Miriam Fernandez, Oscar Iribarne, Peter Jumars, and 3 anonymous reviewers for constructive comments on the manuscript. Financial support for this study was provided by the U.S. Army Corps of Engineers through contrart to David Armstrong and Washington Sea Grant (No. \A36RG0071-01, R/ES-1).

\section{LITERATURE CITED}

Alldredge AL, Hamner WM (1980) Recurring aggregation of zooplankton by a tidal current. Estuar Coast Mar Sci 10 : $31-37$

Aller RC, Dodge RE (1974) Animal-sediment relations in a tropical lagoon Discovery Bay, Jamaica. J Mar Res 32: 209-232

Armistrong DA, Gunderson DR (1985) The role of estuaries in Dungeness crab early life history: a case study in Grays Harbor, Washington. Proceedings of the symposium on Dungeness crab biology and management. Alaska Sea Grant Rept 85-3. University of Alaska, Fairbanks, p $145-170$

Armstrong DA, Iribarne O, Dinnel PA, McGraw KA, Shaffer $J A$, Palacios $R$, Fernandez $M$, Feldman $K$, Williams $G$ (1992) Mitigation of Dungeness crab, Cancer magister. losses due to dredging in Grays Harbor by development of intertidal shell habitat: pilot studies during 1991. FRIUW-9205. University of Washington, Seattle

Armstrong DA, McGraw KA, Dinnel PA. Thom R, Iribarne OO (1991) Construction dredging impacts on Dungeness crab. Cancer magister, in Grays Harbor, Washington and mitigation of losses by development of intertidal shell habitat. FRI-UW-9110. University of Washington, Seattle

Armstrong JL, Armstrong DA, Mathews SB (1995) Food habits of estuarine staghorn sculpin, Leptocottus armatus, with focus on consumption of juvenile Dungeness crab. Cancer magister. Fish Bull US 93:456-470

Barshaw DE, Able KW (1990) Deep burial as a refuge for lady crabs Ovalipes ocellatus: comparisons with blue crabs Callinectes sapidus. Mar Ecol Prog Ser 66:75-79

Barshaw DE, Lavalli KL (1988) Predation upon postlarval lobsters Homarus americanas by cunners Tautogolabrus adspersus and mud crabs Neopanope sayi on three different substrates: eelgrass, mud and rocks. Mar Ecol. Prog Ser 48:119-123

Bertness MD, Gaines SD. Stephens EG, Yund PO (1992) Components of recruitment in populations of the acorn barnacle Semibalanus balanoides (Linnaeus). J Exp Mar Biol. Ecol 156:199-215 
Bird EM (1982) Population dynamıcs of thalassınidean shrimps and community effects through sediment modif1cation. PhD dissertation, University of Maryland, College Park

Blundon. JA, Kennedy VS (1982) Refuges for infaunal bivalves from blue crab, Callinectes sapidus (Rathbun), predation in Chesapeake Bay. J Exp Mar Biol Ecol 65:67-81

Botero L, Atema J (1982) Behavior and substrate selection during larval settling in the lobster Homarus americanus. J Crust Biol 2:59-69

Bourget E, De Guise J, Daigle G (1994) Scales of substratum heterogeneity, structural complexity, and the early establishment of a marne epibenthic community. J Exp Mar Bıol Ecol 181:31-51

Brenchley GA (1981) Disturbance and community structure: an experimental study of bioturbation in manne softsediment environments. J Mar Res 39:767-790

Brenchley GA (1982) Mechanısms of spatial competitıon in marine soft-bottom communitıes. J Exp Mar Bıl Ecol 60 $17-33$

Buchanan DV, Bottom DL, Armstrong DA (1985) The controversial use of the insecticide Sevin in Pacific Northwest ustuaries: its effects on Dungeness crab, Pacific oyster, and other species. Proceedings of the symposium on Dungeness crab biology and management. Alaska Sea Grant Rept 85-3. University of Alaska, Fairbanks, p 401-417

Butman CA (1987) Larval settlement of soft-sediment invertebrates: the spatial scales of pattern explained by active habitat selection and the emerging role of hydrodynamical processes. Oceanogr Mar Biol Annu Rev 25:113-165

Butman CA, Grassle JP. Webb CM (1988) Substrate choices made by marine larvae settling in still water and in a flume flow. Nature 333:771-773

Calinski MD, Lyons WG (1983) Swimming behavior of the puerulus of the spiny lobster Panuhrus argus (Latreille, 1804) (Crustacea: Palinuridae). J Crust Biol 3:329-335

Cobb JS, Wang D, Campbell DB, Rooney P (1989) Speed and direction of swimming by postlarvae of the American lobster. Trans Am Fish Soc 118:82-86

Connell JH (1985) The consequences of variation in instial settlement vs. post-settlement mortality in rocky intertıdal communities. J Exp Mar Biol Ecol 93:11-45

Crisp DJ (1974) Factors influencing the settlement of marine invertebrate larvae. In: Grant PT, Mackie AM (eds) Chemoreception in marine organisms. Academic Press, London, p 177-265

Day RW, Quinn GP (1989) Comparisons of treatments after an analysis of variance in ecology. Ecol Monogr 59:433-463

Dumbauld BR (1994) Thalassinid shrimp ecology and the use of carbaryl to control populations on oyster ground in Washington coastal estuaries. PhD dissertation, University of Washington, Seattle

Dumbauld BR, Armstrong DA, Feldman KL (1996) Lifehistory characteristucs of two sympatric thalassinidean shrimps, Neotrypaea californiensis and Upogebia pugettensis with implications for oyster culture. J Crust Biol 16: $689-708$

Dumbauld BR, Armstrong DA, MCDonald TL (1993) Use of oyster shell to enhance intertidal habitat and mitigate loss of Dungeness crab (Cancer magister) caused by dredging. Can J Fish Aquat Sc1 50:381-390

Eckman JE (1983) Hydrodynamic processes affecting benthic recruitment. Limnol Oceanogr 28:241-257

Eggleston DB, Armstrong DA (1995) Larval supply, active substrate selection, and post-settlement survival as determinants of estuarine Dungeness crab recruitment. Ecol Monogr 65:193-216
Eggleston DB, Lipcius RN, Hines AH (1992) Densitydependent predation by blue crabs upon infaunal clam species with contrasting distribution and abundance patterns. Mar Ecol Prog Ser 85:55-68

Eggleston DB, Lipcius RM, Miller DL, Coba-Cetına L. (1990) Shelter scaling regulates survival of juvenule Cambbean spiny lobster Panulirus argus. Mar Ecol Prog Ser 62:79-88

Fernandez M, Armstrong D, Iribarne $O$ (1993a) First cohort of young-of-the-year Dungeness crab. Cancer magister, reduces abundance of subsequent cohorts in intertidal shell habitat. Can J Fish Aquat Sci 50:2100-2105

Fernandez M, Irıbarne O, Armstrong D (1993b) Habitat selection by young-of -the-year Dungeness crab, Cancer magister Dana and predation risk in intertıdal habitats. Mar Ecol Prog Ser 92:171-177

Fernandez M. Iribarne O, Armstrong D (1994) Swimming behavior of Dungeness crab, Cancer magister Dana megalopae in still and moving water. Estuaries 17:282-286

Gunderson DR, Ellis IE (1986) Development of a plumb staff beam trawl for sampling demersal fauna. Fish Res (Amst) 4:35-41

Hannan CA (1984) Planktonic larvae may act like passive particles in turbulent near-bottom flows. Limnol Oceanogr 29:1108-11:16

Harrison PG (1987) Natural expansion and experimental manipulation of seagrass (Zostera spp.) abundance and the response of infaunal invertebrates. Estuar Coast Shelf Sci 24:799-812

Herrnkind WF, Butler MJ (1986) Factors regulating postlarval settlement and juvenile microhabitat use by spiny lobsters Panulirus argus. Mar Ecol Prog Ser 34:23-30

Holling CS (1959) The components of predation as revealed by a study of small mammal predation of the European pine sawfly. Can J Entomol 91:293-320

Hurlberg LW, Oliver JS (1980) Caging manipulations in marine soft-bottom communities: importance of animal interactions or sedimentary habitat modifications. Can J Fish Aquat Sci 37:1130-1139

lrubarne O, Armstrong D, Fernandez M (1995) Environmental impact of intertidal juvenile dungeness crab habitat enhancement: effects on bivalves and crab foraging rate. J Exp Mar Biol Ecol 192:173-194

Iribarne O, Fernander. M, Armstrong D (1994) Does space competition regulate density of juvenile Dungeness crab Cancer magıster Dana in sheltered habitats? J Exp Mar Biol Ecol 183:259-271

Jacobi CM, Langevin R (1996) Habitat geometry of benthic substrata: effects on arrival and settlement of mobile epifauna. J Exp Mar Biol Ecol 206:39-54

Johns PM, Mann KH (1987) An experimental investigation of juvenile lobster habitat preference and mortality among habitats of varying structural complexity. J Exp Mar Biol Ecol 109:275-285

Johnson GE, Gonor JJ (1982) The tidal exchange of Callianassa californiensis (Crustacea, Decapoda) larvae between the ocean and Salmon River estuary, Oregon. Estuar Coast Shelf Sci 14:501-516

Keough MJ, Downes BJ (1982) Recruitment of marne invertebrates: the role of active larval choices and early mortality. Oecologia 54:348-352

Lemire $M$, Bourget $E$ (1996) Substratum heterogeneity and complexity influence micro-habitat selection of Balanus sp. and Tubularia crocea larvae. Mar Ecol Prog Ser 135: $77-87$

Levin LA (1984) Life history and dispersal patterns in a dense infaunal polychaete assemblage: community structure and response to disturbance. Ecology 65:1185-1200 
Lupcius RN, Hines AH (1986) Variable functional responses of a marine predator in dissimilar homogeneous microhabitats. Ecology 67:1361-1371.

Loosanoff VL, Tommers FD (1948) Effect of suspended silt and other substances on rate of feeding of oysters. Science 107:69-70

Luckenbach MW, Orth RJ (1992) Swimming velocities and behavior of blue crab (Callinectes sapidus Rathbun) megalopae in still and flowing water. Estuaries 15:186-192

MacGinitie GE (1934) The natural history of Callianassa californiensis (Dana). Am Midl Nat 15:166-177

Manning RB, Felder DL (1991) Revision of the American Callianassidae (Crustacea: Decapoda: Thalassinidea). Proc Biol Soc Wash 104:764-792

Meadows PS, Campbell JI (1972) Habitat selection by açuatic invertebrates. Adv Mar Biol 10:271-382

Murphy RC \{1985\} Factors affecting the distribution of the introduced bivalve, Mercenaria mercenaria, in a California lagoon - the importance of bioturbation. J Mar Res $43: 673-692$

Peterson CH (1977) Competitive organization of the softbottom macrobenthic communities of Southern California lagoons. Mar Biol 43:343-359

Posey MH (1986a) Changes in a benthic community associated with dense beds of a burrowing deposit feeder, Callianassa californiensis. Mar Ecol Prog Ser 31:15-22

Posey $\mathrm{MH}$ (1986b) Predation on a burrowing shrimp: distribution and community consequences. J Exp Mar Biol Ecol 103:143-161

Posey MH (1990) Functional approaches to soft-substrate communities: how useful are they? Rev Aquat Sci 2: 343-356

Posey MH, Dumbauld BR, Armstrong DA (1991) Effects of a burrowing mud shrimp, Upogebia pugettensis (Dana), on abundances of macro-infauna. J Exp Mar Biol Ecol 148 ; $283-294$

Ringold P (1979) Burrowing, root mat density, and the distribution of fiddler crabs in the eastern United States. J Exp Mur Biol Ecol 36:11-21

Ronan 'L (1975) Structural and paleo-ecological aspects of a modern marine soft-sediment conmunity: an experimental ficld study. PhD dissertation, University of California. Divis

Simenstad CA, Fresh KL (1995) Influence of intertidal aquaculture on benthic communities in Pacific Northwest estuaries: scales of disturbance. Estuaries 18:43-70

Skalski JR, Robson DS (1992) Techniques for wildlife investigations: design and analysis of capture data. Academic Press, San Diego, California

Snelgrove PVR, Butman CA, Grassle JP (1993) Hydrodynamic enhancement of larval settlement in the bivalve Mulinia lateralis (Say) and the polychaete Capitella sp. I in microdepositional environments. J Exp Mar Bıol Ecol 168:71-109

Sponaugle S, Lawton P (1990) Portunid crab predation on juvenile hard clams: effects of substrate type and prey density. Mar Ecol Prog Ser 67:43-53

Stevens BA (1928) Callianassidae from the west coast of North America. Publs Puget. Sound Mar Biol Stn 6:315-369

Stevens BA (1929) Ecological observations on Callianassidae of Puget Sound. Ecology 10:399-405

This article was presented by K. L. Heck Jr (Senior Editorial Advisor), Dauphin Island, Alabama, USA
Stevens BG, Armstrong DA, Cusimano R (1982) Feeding habits of the Dungeness crab Cancer magister as determined by the index of relative importance. Mar Biol 72 : $135-145$

Stoner DS (1990) Recruitment of a tropical colonia] ascidian: relative importance of pre-settlement vs. post-settlement processes. Ecology 71:1682-1690

Suchanek TH (1983) Control of seagrass communities and sediment distribution by Callianassa (Crustacea, Thalassinidea) bioturbation. J Mar Res 41:281-298

Sulkin SD (1984) Behavioral basis of depth regulation in the larvae of brachyuran crabs. Mar Ecol Prog Ser 15:181-205

Swinbanks DD, Luternauer JL (1987) Burrow distribution of thalassinidean shrimp on a Fraser Delta tidal flat, British Columbia. J Paleont 61:315-332

Swinbanks DD, Murray JW (1981) Biosedimentological zonation of Boundary Bay tidal flats, Fraser River Delta, British Columbia. Sedimentology 28:201-237

Tamaki A (1988) Effects of the bioturbating actuvity of the ghost shrimp Callianassa japonica Ortmann on migration of a mobile polychaete. J Exp Mar Biol Ecol 120 $: 81-95$

Tamaki A, Ingole B (1993) Distribution of juvenile and aduit ghost shrimps, Callianassa japonica Ortmann (Thalassinidea), on an intertidal sand flat: intraspecific facilutation as a possible pattern-generating factor. $\mathbf{J}$ Crust Biol 13: $175-183$

Tankersley RA, McKelvey LM, Forward RB, Jr (1995) Responses of estuarine crab megalopae to pressure, salinity and light: implications for flood-tide transport. Mar Biol 122:391-400

Thrush SF, Pridmore RD, Hewitt JE, Cummings VJ (1992) Adult infauna as facilitators of colonization on intertidal sandflats. J Exp Mar Biol Ecol 159:253-265

Underwood AJ (1981) Techniques of analysis of variance in experimental marine biology and ecology. Oceanogr Mar Biol Annu Rev 19:513-605

Virnstein RW (1978) Predator caging experiments in soft-sediments: caution advised. In Wiley ML (ed) Estuarine interactions. Academic Press, New York, p 261-273

Wainwright $T$, Armstrong DA, Dinnel PA, Orensanz JO, McGraw KA (1992) Predicting effects of dredging on crab populations: an equivalent adult loss approach. Fish Bull US 90:171-182

Washington Department of Fisheries (1970) Ghost shrimp control experiments with Sevin, 1960-1968. Wash Dept Fish Tech Rep 1

Williams GD (1994) Effects of a large-scale estuarine intertidal habitat modification on distribution patterns and food habitats of epibenthic fish species in Grays Harbor, WashIngton. MSc thesis, University of Washington, Seattle

Wilson KA, Able KW, Heck KL (1990) Predation rates on juvenile blue crabs in estuarine nursery habitats: evidence for the importance of macroalgae (Ulva lactuca). Mar Ecol Prog Ser 58:243-251

Woodin SA (1991) Recruitment of infauna: positive or negative cues? Am Zool 31:797-807

Wright LD, Gammisch RA, Byrne RJ (1990) Hydraulic rougtness and mobility of three oyster-bed artificial substrate materials. J Coast Res 6:867-878

Manuscript first received: January 15, 1995

Revised version accepted: March 3, 1997 